\title{
Impacto da tontura na qualidade de vida de idosos com vestibulopatia crônica******
}

\author{
Impact of dizziness on the life quality of elderly with chronic \\ vestibulopathy
}

\author{
Erika Maria dos Santos* \\ Juliana Maria Gazzola** \\ Cristina Freitas Ganança*** \\ Heloisa Helena Caovilla**** \\ Fernando Freitas Ganança*****
}

*Fonoaudióloga. Especialista em Gerontologia pela Universidade Federal de São Paulo (Unifesp). Fonoaudióloga clinica. Endereço para correspondência: R. Visconde de Paranaíba, 1726 - São Paulo - SP - CEP 03164-300 (erika.ems@gmail.com).

**Fisioterapeuta. Doutora em Ciências Otorrinolaringológicas pela Unifesp. Professora do Programa de Mestrado em Reabilitação do Equilíbrio Corporal e Inclusão Social da Universidade Bandeirante de São Paulo.

***Fonoaudióloga. Doutora em Ciências pelo Programa Distúrbios da Comunicação Humana pelo

Departamento Fonoaudiologia da Unifesp. Professora Convidada da Disciplina Distúrbios da Audição do Departamento de Fonoaudiologia da Unifesp.

****Fonoaudióloga. Livre-Docente em Otoneurologia pela Unifesp. Professor Associado do Departamento de Otorrinolaringologia e Cirurgia de Cabeça e Pescoço da Unifesp.

*****Médico. Pós Doutorado em Medicina pela Unifesp - Escola Paulista de Medicina. Professor Adjunto, Chefe da Disciplina de Otologia e Otoneurologia da Unifesp.

******Trabalho Realizado na Disciplina de Otologia e Otoneurologia da Universidade Federal de São Paulo.

Artigo Original de Pesquisa

Artigo Submetido a Avaliação por Pares

Conflito de Interesse: não

Recebido em 01.05.2010.

Revisado em 13.09.2010; 30.10.2010.

Aceito para Publicação em 03.11.2010.

\section{Abstract}

Background: dizziness impact on the quality of life (QoL) of elderly patients with chronic vestibular dysfunction. Aim: to evaluate the association between the impact of dizziness on the QoL of elderly patients with chronic vestibular dysfunction and demographic and clinical variables. Method: a prospective study. A hundred and twenty elderly patients with chronic vestibular dysfunction underwent the Brazilian version of the Dizziness Handicap Inventory (DHI). In order to verify the association between the QoL and the demographic and clinical variables, the following testes were used: Mann-Whitney, KruskalWallis and Spearman's correlation coefficient. Results: there were significant associations between the presence of rotating and non-rotating dizziness with the total score of the DHI $(\mathrm{p}=0.010)$ and physical $(p=0.049)$ and functional $(p=0.009)$ subscales; between recurrent falls with total DHI $(p=0.004)$ and physical $(p=0.045)$, functional $(p=0.010)$ and emotional $(p=0.011)$ subscales. Significant correlations were found between functional incapacity and total DHI $(\mathrm{r}=+0,557 ; \mathrm{p}<0.001)$ and physical $(\mathrm{r}=+$ 0,326; $\mathrm{p}<0.001)$, functional $(\mathrm{r}=+0,570 ; \mathrm{p}<0.001)$ and emotional $(\mathrm{r}=+0,521 ; \mathrm{p}<0.001)$ subscales. Conclusions: the impact of dizziness on the QoL is higher in elderly patients with rotating and nonrotating dizziness, recurrent falls and functional incapacity.

Key Words: Aged; Dizziness; Vestibular Diseases; Quality of Life.

\section{Resumo}

Tema: impacto da tontura na qualidade de vida (QV) em idosos vestibulopatas crônicos. Objetivo: avaliar a associação entre o impacto da tontura na QV de idosos com disfunção vestibular crônica e variáveis demográficas e clínicas. Método: estudo prospectivo em que 120 idosos com disfunção vestibular crônica submeteram-se à versão brasileira do Dizziness Handicap Inventory (DHI). Foram utilizados os testes de Mann-Whitney, Kruskal-Wallis e Coeficiente de Correlação de Spearman para verificar a associação de QV e as variáveis demográficas e clínicas. Resultados: ocorreram associações significantes entre a presença de tontura rotatória e não rotatória com o escore total do DHI $(p=0,010)$ e subescala física $(p=0,049)$ e funcional $(p=0,009)$; entre quedas recorrentes com o DHI total $(p=0,004)$ e subescalas física $(p=$ $0,045)$, funcional $(p=0,010)$ e emocional $(p=0,011)$. Correlações significantes foram encontradas entre incapacidade funcional e o DHI total $(\rho=+0,557$; $\mathrm{p}<0,001)$ e subescalas física $(\rho=+0,326$; $\mathrm{p}<$ $0,001)$, funcional $(\rho=+0,570 ; p<0,001)$ e emocional $(\rho=+0,521 ; p(0,001)$. Conclusões: o impacto da tontura na QV é maior nos idosos com tontura rotatória e não rotatória, quedas recorrentes e incapacidade funcional.

Palavras-Chave: Idoso; Tontura; Doenças Vestibulares; Qualidade de Vida.

Referenciar este material como:

1 Santos EM; Gazzola JM; Ganança CF; Caovilla HH; Ganança FF. Impact of dizziness on the life quality of elderly with chronic vestibulopathy (original title: Impacto da tontura na qualidade de vida de idosos com vestibulopatia crônica). Pró-Fono Revista de Atualização Científica. 2010 out-dez;22(4):427-32. 


\section{Introduction}

Age-related disorders of systems associated to body balance, the greater possibility of chronicdegenerative diseases and the chronic, often multiple, use of medications, among other factors, may favor the manifestation of dizziness or aggravate it, resulting in physical, functional and emotional limitations1.

The elderly individual may present more than one type of dizziness, neurovegetative symptoms, hearing symptoms, psychopathologic and balance disorders that interfere in his locomotion and social autonomy, causing falls and prejudice in daily activities performance2,3.

The prejudices brought by dizziness in quality of life (QoL) have drawn attention of many researchers. The World Health Organization (WHO)4 defined QoL in 1980 as the individual's perception of his position in life, in the cultural context and value system in which he is inserted regarding his goals, expectations, patterns, and preoccupations.

The Dizziness Handicap Inventory (DHI) was designed and validated aiming to assess the selfperception of handicapping effects caused by dizziness5,6. This questionnaire, used in many counties, was also translated and adapted for the Brazilian population, and was used in several researches7-10.

Despite the great prevalence of dizziness among the elderly, scientific literature is scarce regarding studies of QoL in elderly individuals with vestibular disorder, especially concerning the association between the decrease of QoL and clinical and demographic variables. A better knowledge about these associations could directly influence in the identification of the elderly patients with vestibular disorder with greater risk for prejudice in QoL due to dizziness, enabling the choice of a better therapeutic option in the clinical follow-up of such patients.

The aim of this study was to evaluate the association between the impact of dizziness on quality of life of elderly individuals with chronic vestibular dysfunction and clinical and demographic variables.

\section{Method}

This research was carried out under the supervision of the Otoneurology course of the Federal University of São Paulo from August 2006 to March 2007, with the approval of the institution's Ethics Commission, protocol number 1578/06.

It is a prospective study in which 120 elderly patients, aged 65 years old or over, male and female, able to walk and out of a dizziness crisis were included. All patients reported dizziness for at least three months and presented as diagnostic hypothesis, chronic vestibular dysfunction. All patients underwent otoneurological assessment including anamnesis, physical otorhinolaryngological examination, pure tone and speech audiometry, immittance measures, digital vectoelectronistagmography, Brazilian DHI6, analogical visual scale of dizziness, and evaluation of functional capacity by the Brazilian OARS (Olders Americans Research and Services) Multidimensional Functional Assessment Questionnaire - BOMFAQ11. All elderly patients were assessed regarding falls in the past year.

The Brazilian DHI6 was used to assess the interference of dizziness in the patients' QoL. The questionnaire consists of 25 questions divided in three subscales (physical, with seven questions; emotional and functional, with nine questions each). The greater the score, the worse the impact of dizziness on QoL.

The BOMFAQ assesses the functional capacity of elderly individuals according to their report of difficulty for the performance of 15 daily life activities (DLA), eight of them regarding physical activities of daily life and seven regarding instrumental activities of daily life.

The analyzed variables were classified in demographic (gender and age) and clinical data, in order to verify the interference of dizziness in QoL of these patients. The clinical data analyzed were: use of otoneurological medication (yes/no), syndromic and topographic diagnostic of vestibular dysfunction (normal/ peripheral deficitary syndrome/ peripheral irritative syndrome/ central), number of associated vestibular affections (one/two/three or more), time of clinical evolution (3 to 11 months / 1 to 4 years / 5 and more years), type of dizziness (rotatory / non rotatory / both), duration (days / hours / minutes / seconds), and dizziness periodicity (sporadic / monthly / weekly / daily), dizziness analogical visual scale, functional capacity, and falls in the past year (none / one / two and more).

Demographic and clinical variables were related to the total score and to the physical, functional and emotional subscales scores of the DHI. Descriptive and inferential analysis were performed. Non-parametric tests of Mann-Whitney, 
Kruskal-Wallis (followed by the Dunn test, if $\mathrm{p}<0.05$ ) and Spearman correlation (?) were used in the inferential data analysis, once the dependent variables total score, physical subscale score, functional subscale score, and emotional subscale score of the Brazilian DHI did not present normal distribution at the Kolmogorov-Smirnov test. The significance level adopted for the statistical tests was $5 \%(=0.05)$.

\section{Results}

The sample consisted of 120 elderly patients, 38 male (31.7\%) and 82 female (68.3\%). The mean age was 73.5 years old with a standard deviation (SD) of 5.77; the minimum age was 65 years old and the maximum age, 89 years old. The demographic and otoneurological clinical characteristics of the sample are described in another study12.

The mean values, standard deviation and median obtained with the application of DHI were: total score (44.45 \pm 23.02 ; median $=45.00)$, physical subscale score $(13.93 \pm 7.34$; median $=12.00)$, emotional subscale score (13.82 \pm 9.15 ; median $=12.00$ ) and functional subscale score (16.80 \pm 10.18 ; median=16.00).

No significant association was found between the variables gender, age, use of otoneurological medication, syndromic and topographic diagnostic of vestibular dysfunction, associated vestibular affections, time of clinical evolution, dizziness duration and periodicity, and the DHI total score and physical, emotional and functional subscales.

The impact of dizziness on QoL was significantly higher among the elderly who presented association of both types of dizziness (rotatory and non-rotatory); the greatest difference found was among the categories "both" and "nonrotatory dizziness". The total score of DHI was associated to the variable "recurrent falls"; the greatest differences were found between the medians of categories "no falls" and "two or more falls" and also between "one fall" and "two or more falls" (Table 1).
The impact of dizziness on QoL related to the physical subscale was significantly higher among the elderly who presented association of both types of dizziness (rotatory and non-rotatory), and the greatest difference was between the categories "both" and "non-rotatory dizziness". The physical subscale score was associated to the variable "recurrent falls"; the greatest differences were found between the medians of the categories "one fall" and "two or more falls" (Table 1).

The impact of dizziness on QoL related to the functional subscale was significantly higher among the elderly who presented association of both types of dizziness (rotatory and non-rotatory), and the greatest difference found was between the categories "both" and "non-rotatory dizziness". The functional subscale score was associated to the variable "recurrent falls"; the greatest differences were found between the medians of the categories "one fall" and "two or more falls" (Table 1).

The variable "type of dizziness" presented a tendency to statistical difference with the score of the emotional subscale of DHI; the greatest differences were found between the medians of categories "rotatory dizziness" and "both". The score of the emotional subscale was associated to "recurrent falls", and the greatest differences were found between the medians of the categories "none" and "two and more falls" and "one fall" and "two or more falls" (Table 1).

The dizziness intensity, verified by the analogical visual scale, did not present significant correlation with the DHI total score $(\mathrm{p}=0.161$; $=+0.129)$, and physical $(\mathrm{p}=0.112 ;=+0.146)$, and emotional subscales scores $(\mathrm{p}=0.830$; $=-0.020)$, and presented significant correlation with the score of the functional subscale $(\mathrm{p}=0.033$; $=+0.195)$.

A significant positive correlation was verified between the DHI total score $(\mathrm{p}<0.001 ;=+0.557)$, and the physical $(\mathrm{p}<0.001 ;=+0.326)$, functional $(\mathrm{p}<0.001 ;=+0.570)$ and emotional $(\mathrm{p}<0.001$; $=+0.521$ ) subscales scores with the number of affected daily life activities; it was observed a great impact of dizziness on QoL of the elderly with a higher number of affected activities. 
TABIE 1. Mean values, standard deviation and median of total score, of physical, functional and emotional subscales scores obtained with the application of the Brazilian version of the Dizziness Handicap Inventory, according to the categories of clinical variablestype of diziness and falls in the past year in elderly individuals with chronic vestibulardisorder $(n=120)$

\begin{tabular}{|c|c|c|c|c|c|}
\hline DHI & Variables & Categories & Mean (SD) & Median & p-value \\
\hline \multirow{2}{*}{$\begin{array}{l}\text { Total } \\
\text { Score }\end{array}$} & Type of Dizziness & $\begin{array}{c}\text { Rotatory diziness } \\
\text { Non-rotatory dizuness } \\
\text { Both }\end{array}$ & $\begin{array}{l}33.71(23.42) \\
37.43(20.83) \\
47.77(22.89)\end{array}$ & $\begin{array}{l}42.00 \\
36.00 \\
48.00\end{array}$ & $0.010^{a}$ \\
\hline & $\begin{array}{c}\text { Falls in the past } \\
\text { year }\end{array}$ & $\begin{array}{c}\text { No falls } \\
1 \text { fall } \\
2 \text { and more falls }\end{array}$ & $\begin{array}{l}42.80(20.58) \\
37.50(21.95) \\
52.20(25.28)\end{array}$ & $\begin{array}{l}42.00 \\
38.00 \\
53.00\end{array}$ & $0.004^{a}$ \\
\hline \multirow{2}{*}{$\begin{array}{l}\text { Physical } \\
\text { Subscale }\end{array}$} & Type of Dizziness & $\begin{array}{c}\text { Rotatory diziness } \\
\text { Non-rotatory dizuness } \\
\text { Both }\end{array}$ & $\begin{array}{l}10.57(6.29) \\
12.00(7.58) \\
15.28(7.36)\end{array}$ & $\begin{array}{l}10.00 \\
12.00 \\
16.00\end{array}$ & 0.049 a \\
\hline & $\begin{array}{l}\text { Falls in the past } \\
\text { year }\end{array}$ & $\begin{array}{c}\text { No falls } \\
1 \text { fall } \\
2 \text { and more falls }\end{array}$ & $\begin{array}{l}13.89(6.87) \\
11.52(6.88) \\
16.00(7.99)\end{array}$ & $\begin{array}{l}14.00 \\
12.00 \\
16.00\end{array}$ & $0.045^{a}$ \\
\hline \multirow{2}{*}{$\begin{array}{l}\text { Functional } \\
\text { Subscale }\end{array}$} & Type of Dizziness & $\begin{array}{l}\text { Rotatory diziness } \\
\text { Non-rotatory diziness } \\
\text { Both }\end{array}$ & $\begin{array}{l}14.86(10.95) \\
12.79(9.13) \\
18.29(9.91)\end{array}$ & $\begin{array}{l}14.00 \\
11.00 \\
18.00\end{array}$ & 0.009 a \\
\hline & $\begin{array}{c}\text { Falls in the past } \\
\text { year }\end{array}$ & $\begin{array}{c}\text { No falls } \\
1 \text { fall } \\
2 \text { and more falls }\end{array}$ & $\begin{array}{c}15.80(9.69) \\
14.17(9.56) \\
19.80(10.31)\end{array}$ & $\begin{array}{l}14.00 \\
14.00 \\
22.00\end{array}$ & $0.010^{a}$ \\
\hline \multirow{2}{*}{$\begin{array}{l}\text { Emotional } \\
\text { Subscale }\end{array}$} & Type of Dizziness & $\begin{array}{c}\text { Rotatory diziness } \\
\text { Non-rotatory dizuness } \\
\text { Both }\end{array}$ & $\begin{array}{c}8.00(7.71) \\
11.87(7.88) \\
15.10(9.45)\end{array}$ & $\begin{array}{c}8.00 \\
12.00 \\
16.00\end{array}$ & $0.056^{a}$ \\
\hline & $\begin{array}{c}\text { Falls in the past } \\
\text { year }\end{array}$ & $\begin{array}{c}\text { No falls } \\
1 \text { fall } \\
2 \text { and more falls }\end{array}$ & $\begin{array}{l}12.82(8.33) \\
11.24(9.00) \\
17.54(9.63)\end{array}$ & $\begin{array}{l}12.00 \\
10.00 \\
18.00\end{array}$ & $0.011^{a}$ \\
\hline
\end{tabular}

\section{Legend:}

DHI: Dizziness Handic ap Inventory; a Kruskal-Wallis Test; SD Standard Deviation; Signific ance $\alpha=0,05$.

\section{Discussion}

The DHI was the questionnaire used in this research since it is the only specific questionnaire translated and culturally adapted for the Brazilian population to measure the effects of dizziness. It was verified that the prejudice in the QoL of elderly patients with vestibular disorder did not depend on the age and gender.

In the present study, the elderly patients with chronic vestibular dysfunction presented a mean total score of DHI considered of moderate impact13. The mean total score could have been greater if the 
study sample had also included elderly patients who don't deambulate and in a dizziness crisis.

A significant relation was identified between the presence of rotatory or non-rotatory dizziness with the total score of DHI and the physical and functional subscales scores. The presence of more than one type of dizziness in elderly patients may occur as a result of a single vestibular disorder with pluriform clinical manifestation regarding the type of dizziness, by more than one concomitant vestibular disorder, or by the prejudice of different sensorial systems involved in body balance12. Elderly individuals present more than one type of dizziness, and many times these symptoms are chronic14. Uncompensated and progressive vestibular disorders and/or associated to damages in other systems involved in the body balance could also provoke greater prejudices to physical, functional and emotional aspects of QoL.

The use of otoneurological medication was not associated to worse or better QoL regarding the elderly who did not use it, probably because in the chronic phase of the uncompensated vestibular disorder, the pharmacotherapy does not have much effect regarding the aspects investigated by the DHI.

The impact of dizziness on the QoL of elderly patients with vestibular disorder did not show correlation with the different syndromic and topographic diagnostics presented by them, evidencing that what prejudices QoL is the dizziness itself and not its syndromic or topographic origin. Accordingly, the association of concomitant vestibular disorders was not associated to alteration of dizziness impact on QoL regarding those elderly with only one vestibular disorder, evidencing that the worsening of QoL depends on the presence of dizziness and not on how many vestibular disorders generate it.

The dizziness duration, periodicity and time of clinical evolution also didn't show relation with the impact of dizziness on QoL of elderly individuals with vestibular disorder, evidencing, once more, that the prejudices on these patients' QoL are due to the presence of dizziness independently of its characteristics.

A more intense dizziness pointed by the analogical visual scale presented significant relation to the functional subscale score of DHI, indicating that the performance of professional, domestic, social and leisure activities, and also tasks such as walking with assistance and difficulty to walk at home in the dark1, may increase the risk for dizziness or its worsening, becoming more difficult for elderly individuals with vestibular disorder. Furthermore, the performance of these activities is harder for elderly individuals who feel a more intense dizziness, that is, reinforcing the restrictive functional character of intense dizziness in this population.

In the present study, it was verified a significant relation between the total score and the scores of physical, functional and emotional subscales of DHI with the occurrence of falls in the past year $(p<0,05)$. Falls may determine complications that alter the QoL of elderly, since they present negative impact such as important morbidity, mortality, functional deterioration, hospitalization, institutionalization, and use of social and health services15. A worse QoL was also found by Ribeiro et al.16, at the WHOQOL-Bref domains, in elderly individuals who fell in the past year when compared to those who didn't fall in this period, being more evident in the psychological domain. The increase of independence of elderly people, the negative feelings, memory and concentration disorders, low self-esteem and alteration in body image could justify these findings16.

The correlation of the BOMFAQ instrument with the total score and the physical, functional and emotional subscales scores of DHI presented significant relation, showing that the elderly with more difficulty to perform physical and instrumental daily life activities have a worse impact of dizziness on QoL. Likewise, the lack of autonomy or the greater difficulty to perform physical and instrumental daily life activities restrict the elderly, provoking physical, functional, and certainly emotional prejudice. These findings were found in elderly individuals with vestibular disorder assessed by the same evaluation instrument of functional capacity 17.

The maintenance of functional capacity of the elderly is crucial for the their health preservation 11. The better capacity to perform DLA is associated to a better QoL18. The preserved functional capacity is a predictor of a well succeeded aging19.

The present study demonstrated that elderly individuals with chronic vestibular disorder present impact on QoL concerning all aspects assessed by the DHI, and damage in the functional capacity, interfering in the physical and social independency.

We believe that the administration of therapeutic options that reduce the negative impacts interfering on QoL is fundamentally important for the adequate assistance of this population. Assistance and intervention programs are important for the reduction of prejudices on QoL of elderly with reduced functional capacity20. 


\section{Conclusions}

The impact of dizziness on QoL of elderly individuals with chronic vestibular disorders is greater in patients with rotatory and non-rotatory dizziness, recurrent falls, neurovegetative symptoms, hypersensitivity to sounds and functional capacity disorder regarding the total score and physical and functional subscales scores of DHI, and in the elderly with recurrent falls, neurovegetative symptoms and functional capacity disorder regarding the score of emotional subscale of DHI.

\section{References}

1. Ganança FF, Castro ASO, Branco FCA, Natour J. Interferência da tontura na qualidade de vida de pacientes com síndrome vestibular periférica. Rev Bras Otorrinolaringol. 2004;70(1):94-101.

2. Ruwer SL, Rossi AG, Simon LF. Balance in the elderly. Rev Bras Otorrinolaringol. 2005;71(3):298-303.

3. Gazzola JM, Perracini MR, Ganança MM, Ganança FF. Fatores associados ao equilíbrio funcional em idosos com disfunção vestibular crônica. Rev Bras Otorrinolaringol. 2006 Out;72(5):683-90.

4. World Health Organization. International classification of impairments, disabilities and handicaps: a manual of classification relating to the consequences of disease, published in accordance with resolution WHA29.35 of the Twenty-ninth World Health Assembly. May 1976. Geneva, World Health Organization; 1980. p. 205.

5. Jacobson GP, Newman CW. The development of the dizziness handicap inventory. Arch Otolaryngol Head Neck Surg. 1990;116(4):424-7.

6. Castro ASO, Gazzola, JMG, Natour J, Ganança FF. Brazilian version of the dizziness handicap inventory. Pro Fono. 2007;19(1):97-104.

7. Cunha F, Settanni FAP, Ganança FF. What is the effect of dizziness on the quality of life for patients with Meniere's disease? Rev Laryngol Otol Rhinol. 2005;126,3:155-8.

8. Handa PR, Kuhn AM, Cunha F, Schaffleln R, Gananca FF. Quality of life in patients with benign paroxysmal positional vertigo and/or Meniere's disease. Rev Bras Otorrinolaringol. 2005;71(6):776-82.

9. Segarra-Maegaki JA, Taguchi CK. Study about the benefits of vestibular rehabilitation in peripheral vestibular disorders. Pro Fono. 2005;17(1):3-10.

10. Gabilan YP, Perracini MR, Munhoz MS, Ganança FF. Aquatic physiotherapy for vestibular rehabilitation in patients with unilateral vestibular hypofunction: exploratory prospective study. J Vestib Res. 2008;18(23):139-46.
11. Ramos LR, Rosa TEC, Oliveira ZM, Medina MCG, Santos FRG. Perfil do idoso em área metropolitana na região sudeste do Brasil: resultados de inquérito domiciliar. Rev Saúde Pública. 2003;27(2):87-94.

12. Gazzola JM, Ganança FF; Aratani MC, Perracini MR, Ganança MM. Caracterização clínica de idosos com disfunção vestibular crônica. Rev Bras Otorrinolaringol. 2006;72(4):515-22.

13. Whitney SL, Wrisley DM, Brown KE, Furman JM. Is Perception of Handicap Related to Functional Performance in Persons with Vestibular Dysfunction? Otol Neurotol. 2004;25(2):139-43.

14. Felipe L, Cunha LC, Cunha FC, Cintra MT, Gonçalves DU. Presbyvertigo as a cause of dizziness in elderly. Pro Fono. 2008 Apr-Jun;20(2):99-103.

15. Masud T, Morris RO. Epidemiology of falls. Age Ageing. 2001 Nov;30 Suppl 4:3-7.

16. Ribeiro AP, de Souza ER, Atie S, de Souza AC, Schilithz AO. The influence of falls on the quality of life of the aged. Cien Saude Colet. 2008 Jul-Aug;13(4):1265-73.

17. Aratani MC, Perracini MR, Caovilla HH, Gazzola JM, Ganança MM, Ganança FF. Disability rank in vestibular older adults. Geriatr Gerontol Int. 2010 Jun 29.

18. Lee T, Ko IS, Lee K. Health promotion behaviors and quality of life among community-dwelling elderly in Korea: a cross-sectional survey. Int J Nurs Stud. 2006 Mar;43(3):293-300.

19. Moraes J, Souza V. Fatores associados ao envelhecimento de idosos socialmente ativos da região metropolitana de Porto Alegre. Rev Bras Psiquiatr. 2005;27(4):302-8.

20. Asakawa T, Koyano W, Ando T, Shibata H. Effects of functional decline on quality of life among the Japanese elderly. Int J Aging Hum Dev. 2000;50(4):319-28. 